\title{
Simulation of ozone production in a complex circulation region using nested grids
}

\author{
M. Taghavi, S. Cautenet, and G. Foret \\ Laboratoire de Météorologie Physique, OPGC-CNRS and Université Blaise Pascal, Aubière, France
}

Received: 2 February 2003 - Published in Atmos. Chem. Phys. Discuss.: 25 July 2003

Revised: 24 May 2004 - Accepted: 25 May 2004 - Published: 4 June 2004

\begin{abstract}
During the ESCOMPTE precampaign (summer 2000, over Southern France), a 3-day period of intensive observation (IOP0), associated with ozone peaks, has been simulated. The comprehensive RAMS model, version 4.3, coupled on-line with a chemical module including 29 species, is used to follow the chemistry of the polluted zone. This efficient but time consuming method can be used because the code is installed on a parallel computer, the SGI 3800. Two runs are performed: run 1 with a single grid and run 2 with two nested grids. The simulated fields of ozone, carbon monoxide, nitrogen oxides and sulfur dioxide are compared with aircraft and surface station measurements. The 2-grid run looks substantially better than the run with one grid because the former takes the outer pollutants into account. This on-line method helps to satisfactorily retrieve the chemical species redistribution and to explain the impact of dynamics on this redistribution.
\end{abstract}

\section{Introduction}

During the last century, the atmospheric composition has been modified considerably by human activities. One of the consequences of this change is the high ozone concentrations observed in polluted zones. In recent years, high ozone concentrations have been reported in the south of France, due to high anthropogenic and biogenic emissions. For this reason, southern France has chosen as the focus in the ESCOMPTE campaign (Cros et al., 2004). High concentrations of ozone and other photochemical oxidants have an impact on the lung function of human beings (Bates, 1995a, b) and are recognized as having negative effects on public health, crops and forests (Taylor, 1969; Heck et al., 1984). In order to study the transport of pollutants and their chemical regime, it is

Correspondence to: $\mathrm{M}$. Taghavi

(m.taghavi@opgc.univ-bpclermont.fr) hence very important to assess ozone production. For instance, the Current Directive 92/72/EEC for the European Union requires that the member states set and continually monitor the $\mathrm{O}_{3}$ thresholds, with emphasis on excess concentration cases (Gangoiti et al., 2002). A numerical model describing meteorology, pollutant emission, transport, chemistry, and deposition is a powerful tool to address the problem of air quality and to develop effective control strategies. This type of model must undergo a validation step using reliable observational data, which ensures, to some extent, its accuracy. In fact, some uncertainty is inevitable, because there are more than 3000 different chemical species in the atmosphere involved in complex chemistry. For instance, the explicit oxidation mechanism of even one organic compound includes hundreds of reactions. Hence, the amount of reactions quickly becomes unmanageable for a $\mathrm{VOC}-\mathrm{NO}_{\mathrm{x}}$ mixture when the number of organics increases. An example of a complex explicit mechanism is the NCAR gas-phase master mechanism (Madronich and Calvert, 1989), with 4930 chemical reactions. Thus, there are three major problems: (i) a large CPU time is required for an explicit solution; (ii) the wide range covered by the chemical timescales leads to highly stiff systems which require specific solvers (Djouad and Sportisse, 2002); (iii), as a general rule, kinetic coefficients and emission rates are not available for each organic species but for a whole group. As a result, these explicit chemical mechanisms are not used in pollution studies except to describe the inorganic $\mathrm{NO}_{\mathrm{x}}$ chemistry, which is relatively straightforward. Condensed schemes are therefore commonly used (Aumont et al., 1996).

The chemistry/transport models can be coupled either online or offline with meteorological models. In the "offline" case, the frequency of the sampling rate of the meteorological fields must be considered with regards to transport. For example, a 3-h frequency is used in the offline coupling of the LOTOS model (VanLoon et al., 2000) whereas a 1-h frequency is taken for TVM (meteorological model) coupled 
offline with the chemistry model RACM (Thunis and Cuvelier, 2000). It is obvious that in these cases we cannot have good accuracy in the species transport, because the meteorological data are averaged in time. The emission rates and the transport play an important role in the chemistry regime for the mesoscale studies, especially in the case of complex circulation. For instance, if we use a 3-hourly meteorological dataset, a problem arises during the afternoon, as at 16:00 LST, we may be in a sea breeze regime; whereas at 19:00 LST, the land breeze onset already may be effective. On the other hand, the offline method is useful in large scale studies.

The lateral boundary conditions may represent another serious problem. As a general rule, in offline mode, modelers derive boundary conditions either from measurements or from clean air values. These values are held constant and homogeneous along large parts of the boundary. However, Winner et al. (1995) showed that the boundary values can strongly impact the simulation quality. In other words, one must pay close attention to the boundary conditions. To get rid of this problem, we use a nested grid approach. This is a quite common practice in meteorological mesoscale modeling, but it is a new method in chemistry/transport modeling. With the nested grid method, the pollutant concentration arriving at the boundary of a fine grid depends on time and on the location of the boundary grid point. This method takes into account the pollutant sources far from the studied domain (the finest grid).

The aim of this study is to develop a chemistry/transport model which reconciles two antagonistic requirements: a minimum CPU time and a maximum accuracy. To this end, we use an online coupling between the meteorological and the photochemical models with two nested grids, since computers like SGI 3800 are very powerful and fast for parallel codes. We have coupled online the RAMS (Regional Atmospheric Modeling Systems) mesoscale model (Cotton et al., 2003) with the MOCA 2.2 chemical model (Aumont et al., 1996). This coupled model is hereafter referred to as "RAMS-chemistry". We have focused on transport, dynamics impact, and chemical redistribution from primary or secondary species.

In this paper, we summarize the context of the ESCOMPTE precampaign. Then we present the emission database and the meteorological model. We examine the meteorological conditions during the pollution period and compare the modeled meteorological fields with the observed values (surface station and aircraft measurements). Then, we describe the chemistry mechanism (code MOCA 2.20) coupled online with RAMS. In the fine grid, we compare the modeled ozone, carbon monoxide, nitrogen oxides, and sulfur dioxide fields with aircraft and surface observations. Finally, we discuss the role of dynamics in the redistribution of the modelled species.

\section{ESCOMPTE pre-campaign}

The ESCOMPTE precampaign was conducted in June and July 2000 in southeastern France (http://medias.obs-mip.fr/ escompte). During this period, an Intensive Observation Period (IOP0) took place on 29, 30 June and 1 July. For these three days, data from meteorological and chemical surface stations and aircraft measurements are available. For the modeling group, the aim of this precampaign was to perform runs in order to derive flight plans and to find the best locations for the surface stations. Moreover, it was projected that the chemical and meteorological data gathered during this period would be useful to validate the models.

The detailed IOP0 database consists of: (i) the anthropogenic and biogenic emission inventory, with two different resolutions (15 km and $3 \mathrm{~km}$ ); (ii) information about meteorological conditions during the pollution period; (iii) surface measurements (fixed and mobile stations) for both meteorological and chemical data; (iv) airborne measurements (aircrafts and balloons). Two aircrafts were operated: the PIPER AZTEC plane (MétéoFrance) and the INSU (Institut National des Sciences de l'Univers) ARAT plane. Several flights occurred during the studied days. Some of the main objectives of the ESCOMPTE campaign were to answer the following questions:

1. What is the respective role of the various dynamic and chemical mechanisms on the pollutant redistribution?

2. How should urban emissions be taken into account in regional or global models?

3. Can we develop an operational forecast of pollution periods?

4. What strategy should be developed in order to reduce the pollutant concentrations?

\section{Meteorological modelling description}

The RAMS model (Regional Atmospheric modelling System; http://www.atmet.com; Cotton et al., 2003) is a parallel mesoscale model allowing the simulation of meteorological fields with horizontal scales spanning from one kilometer to a thousand kilometers. It includes nested grids. Many investigations on regional pollution were previously made using the RAMS model (Lyons et al., 1995; Millan et al., 1997; Edy and Cautenet, 1998; Cautenet et al., 1999; Poulet et al., submitted, 2004 ${ }^{1}$ ).

Simulations have been performed using two nested grids simultaneously to take synoptic and local circulations into account. In a simulation with two nested grids, each grid covering a particular domain size (Fig. 1), a two-way interactive

\footnotetext{
${ }^{1}$ Poulet, D., Cautenet, S., and Aumont, B.: Simulation of the chemical impact of the bush fires emissions, in central africa, during the EXPRESSO campaign, submitted to J. Geophys. Res., 2004.
} 

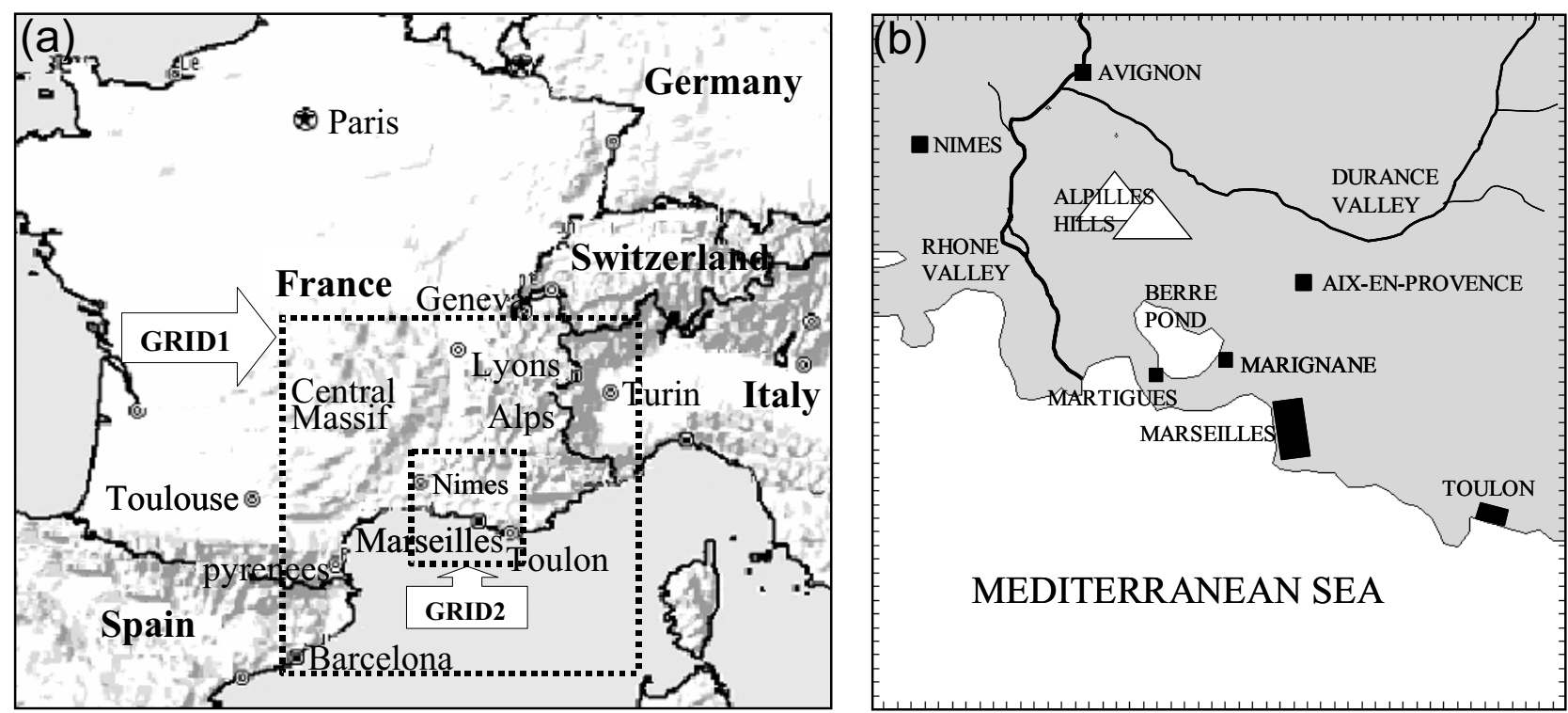

Fig. 1. (a) Geographical map and configuration of nested grids, grid 2 represents the ESCOMPTE domain; (b) a zoom on grid 2 with location of some observation stations.

process is involved. Grid 1 covers southern France, a part of Northern Spain and a part of Northern Italy, resulting in 36 square meshes of $15 \mathrm{~km}$. Grid 2 represents the ESCOMPTE domain. It has 52 meshes of $3 \mathrm{~km}$. We use a time step of $10 \mathrm{~s}$ and 35 levels in the vertical dimension (the same in both grids) with 15 levels from surface to $1500 \mathrm{~m}$, which ensures a fine description of the boundary layer. The coarse domain includes the cities of Lyons, Turin, and Barcelona, to the north, east and southwest respectively. Moreover, it comprises the Pyrenées, Massif Central and Alps mountain ranges. This topography introduces a complex circulation associated with sea breeze. In the fine grid (grid 2), we have the cities of Marseilles, Toulon and Avignon, with the Alpilles hills and the Durance and Rhone valleys.

In the model, the initial meteorological fields and the 6h-nudging are provided by the ECMWF (European Centre for Medium-Range Weather Forecasts) database. The simulation starts on 28 June 2000 at 00:00 UTC and ends on 1 July 2000 at 21:00 UTC. The soil vegetation model includes 30 classes issued from USGS (United States Geophysical Survey) with a $1 \mathrm{~km}$ resolution. The "patches" configuration (Cotton et al., 2003) allows part of the $1 \mathrm{~km}$ information to be retained. The USGS topography also has a $1 \mathrm{~km}$ resolution and an interpolation is performed. The sea surface temperature is obtained from Meteosat. Near the coastline, these temperatures are corrected using the OOM (Observatoire d'Océanographie de Marseille) shore temperature.

In this run, the reflected envelope topography scheme is used and aims to preserve both barrier heights and valley depths. The vertical diffusion is computed from the Smagorinsky scheme (Tripoli and Cotton, 1982), where ad- justments to the vertical exchange coefficients are made using a Richardson number/moist Brunt-Vaisala frequency enhancement factor. The full microphysics scheme is not implemented, because it is an event of fair weather, but the condensed water is calculated and the cloud cover is taken into account in the radiation code (Chen and Cotton, 1988).

\section{Emissions}

\subsection{Anthropogenic emissions}

A key point of atmospheric chemistry is the influence of human activity on emissions. For example, humans have doubled the natural rate of nitrogen fixation (Vitousek et al., 1997). In fact, one of the important reasons to study atmospheric chemistry in southeastern France is the high level of anthropogenic emissions due to the presence of many industrial factories, oil refineries, EDF (France Electricity) power stations and other large factories such as "Air Liquid", situated in the industrial zones of Fos-Sur-Mer or Berre Pond. Additional emissions are due to highways and polluted cities like Marseilles and Toulon on the coast, Aix-en-Provence or Avignon inland. These high anthropogenic emissions are illustrated in Fig. 2 where the $\mathrm{NO}_{\mathrm{x}}$ emissions are shown at 12:00 UTC for a typical July working day.

\subsection{Biogenic emission}

This region is covered by Mediterranean vegetation and provides important biogenic emissions. This type of vegetation exhibits an annual cycle of biogenic emissions characterized by a rapid growth in March, a maximum in July-August and 


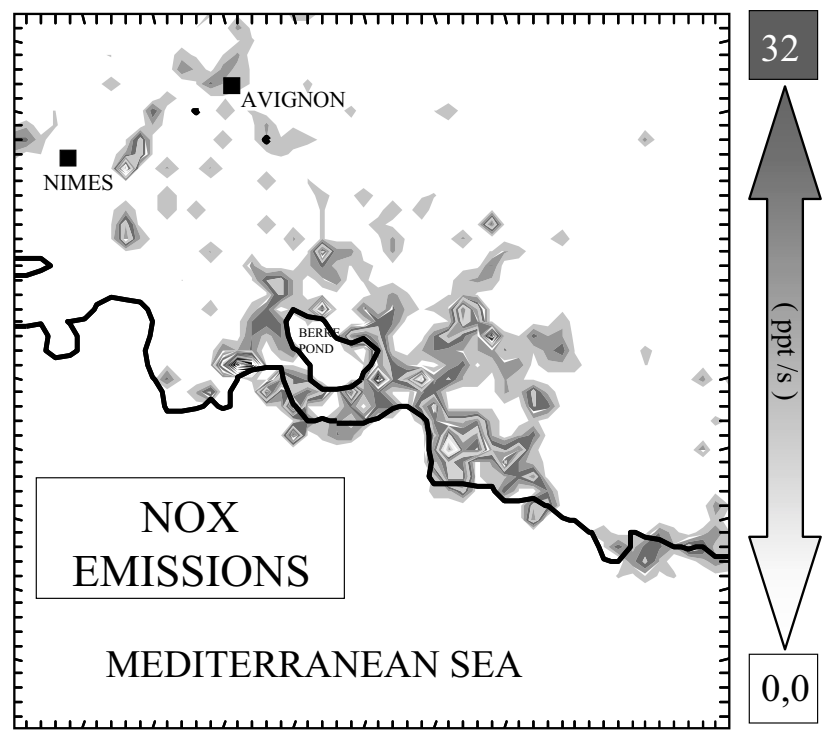

Fig. 2. $\mathrm{NO}_{\mathrm{x}}$ emission map for an ordinary day of July at 12:00 UTC.

a strong decrease in September-October. Isoprene appears as the most abundant species (Simon et al., 2001). This compound is due mainly to Holm oak. In Fig. 3, we can see the isoprene emissions at 12:00 UTC for an ordinary day of July.

\subsection{Database}

For grid 1 with a resolution of $15 \mathrm{~km}$, the emissions were obtained from the GENEMIS database. For the fine domain (grid 2), we used an inventory derived from GENEMIS, which we have added area sources for the industrial and urban regions from data of 1994 (http://medias.obs-mip. fr/escompte/projet/index.fr.php). For both grids, emissions were calculated from data of 1994 for anthropogenic emissions and 1997 for biogenic emissions. Hourly values were supplied for each mesh and for two days: (5 and 6 July 1994) for anthropogenic sources and (21 and 22 July 1997) for biogenic sources. An inventory with a high resolution and updated emissions, specially performed for the ESCOMPTE domain must be available in 2004 (François et al., 2004; Taghavi et al., 2004).

\section{The two ways nesting method}

In mesoscale chemical and meteorological modeling, the boundary conditions must be specified. Modeling can be strongly influenced by them, especially when there is a strong flow crossing the borders. For chemistry/transport models, the existence of a high emission zone near the studied domain can be significant because a strong wind may transport a large amount of the emitted pollutants from the outside source into the model domain. The boundary conditions can be provided by global modeling results which

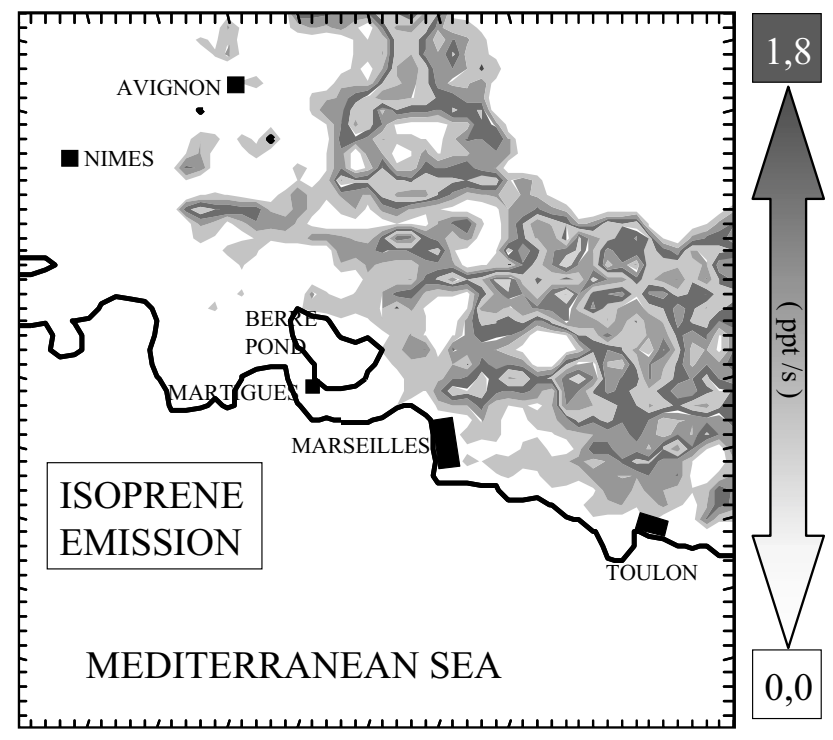

Fig. 3. Isoprene emission map for an ordinary day of July at 12:00 UTC.

generally have a resolution of about $100 \times 100 \mathrm{Km}$ or more. This crude resolution is not sufficient to obtain realistic results with respect to chemistry. In our study, we wanted to realistically retrieve the chemical fields in grid 2 . In fact, the coarse grid or grid $1(15 \times 15 \mathrm{Km})$ was used to provide boundary values for the fine grid or grid $2(3 \times 3 \mathrm{Km})$. The two way nesting method is very effective to obtain realistic simulations because at each time step, the fine grid (grid 2) provides its data to the coarser (mother) grid, which in turn forces the fine (daughter) grid. The two grids communicate with each other in a two-way scheme described by Clark and Farley (1984) and Walko et al. (1995). In particular, such a scheme allows emissions far outside grid 2 to influence the pollutant budget within grid 2 . This method helps to explain the impact of pollutants emitted from Lyons, Barcelona, and Turin that are transported to the ESCOMPTE region. The pollutants from Lyons are channeled along the Rhone valley and have an impact on the ozone production in the ESCOMPTE domain.

\section{High-resolution meteorological simulation: compari- son with surface station and airborne measurements}

The redistribution of pollutants and therefore the ozone production is very dependent on the meteorological conditions. The observed meteorological situation during IOP0 ranged between clear to slightly cloudy conditions. These conditions promote significant photochemical activity. On 29 June, wind direction was west to northwest (Mistral), and wind speed was from moderate to strong, locally exceeding $12 \mathrm{~ms}^{-1}$. The maximum temperatures reached about 29 $30^{\circ} \mathrm{C}$. On 30 June, the wind turned from north to west, and a 

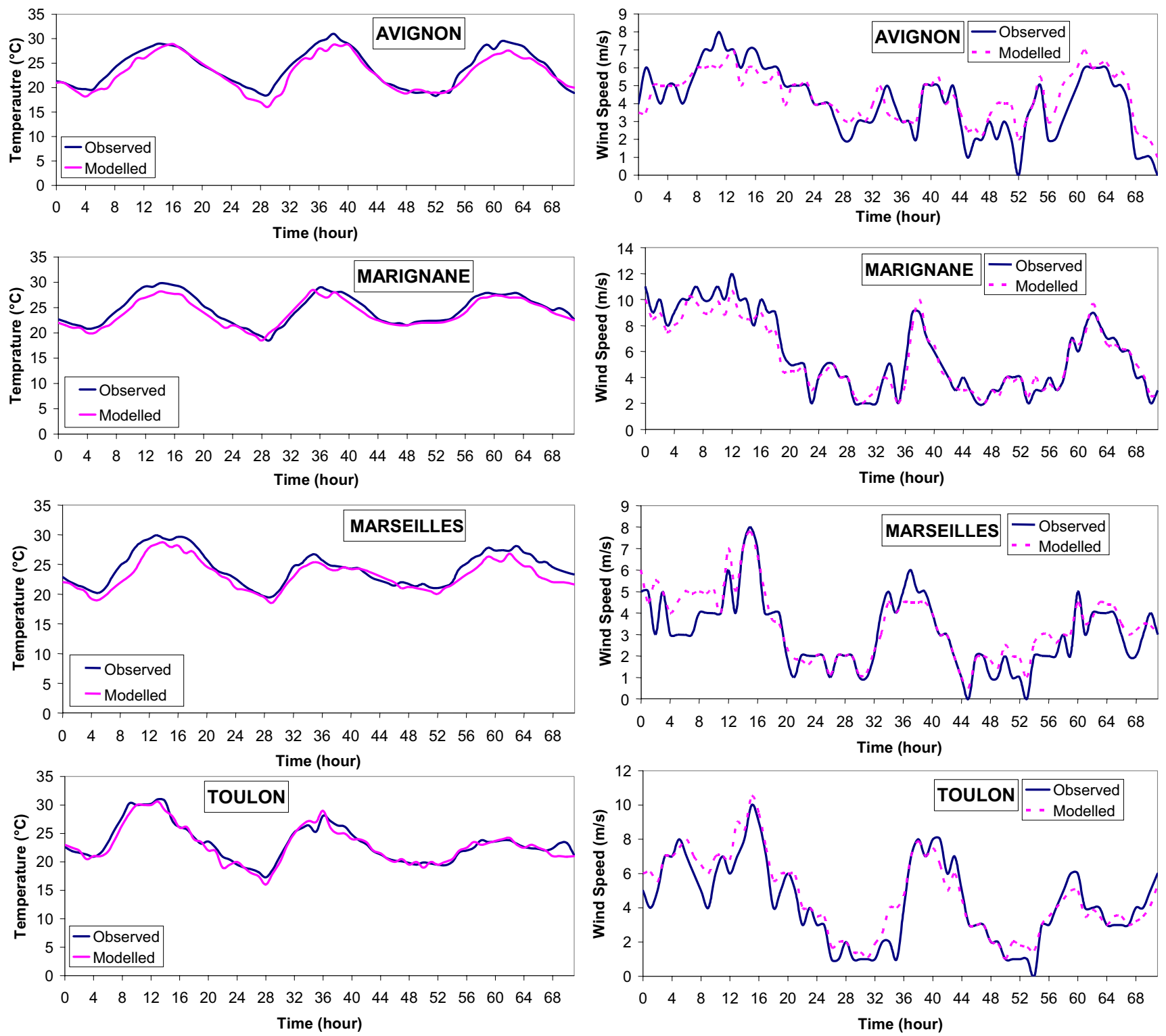

Fig. 4. Time variation (UTC) of temperature and wind speed from 29 June-1 July 2000 for 4 cities, Avignon inland in north of ESCOMPTE domain, Marignane in center, Marseilles and Toulon on the coast.

sea breeze developed in the afternoon with speeds from 4 to $7 \mathrm{~ms}^{-1}$. The maximum temperatures were around $30^{\circ} \mathrm{C}$. On 1 July, the sea breeze was enhanced by a southwest flow and the speeds were slightly greater: 5 to $8 \mathrm{~ms}^{-1}$, and the maximum temperatures were lower than the day before (between $25^{\circ} \mathrm{C}$ and $30^{\circ} \mathrm{C}$ ). On 30 June, the conditions which promote the formation of ozone peaks were fulfilled, i.e. high temperature and weak wind.

To validate the simulated meteorological fields, we compared the model results with surface station and airborne measurements. Some of these comparisons are shown in Figs. 4 and 5. To compare the model results with the station data, we use a statistical method (Cai and Steyn, 2000).
In fact, we have many stations (about 5) for each of the 4 towns in the model area (Marseilles, Marignane, Toulon and Avignon). These data can be strongly influenced by local effects. Marseilles and Toulon are located near the coast, Marignane lies in the center of the domain and Avignon is the furthest inland. The hourly station data comes from averaged data taken at 15-min intervals. In Fig. 4, we note that the observed and the modeled temperature values for the three days are in good agreement for all the surface stations. It is the same for the wind speed (Fig. 4). However, we remark that in Marignane, located close to pollutant sources (Figs. 1b and 2), the wind speed reaches the highest values $\left(12 \mathrm{~ms}^{-1}\right)$ on 29 June. This favors pollutant dispersion. We 

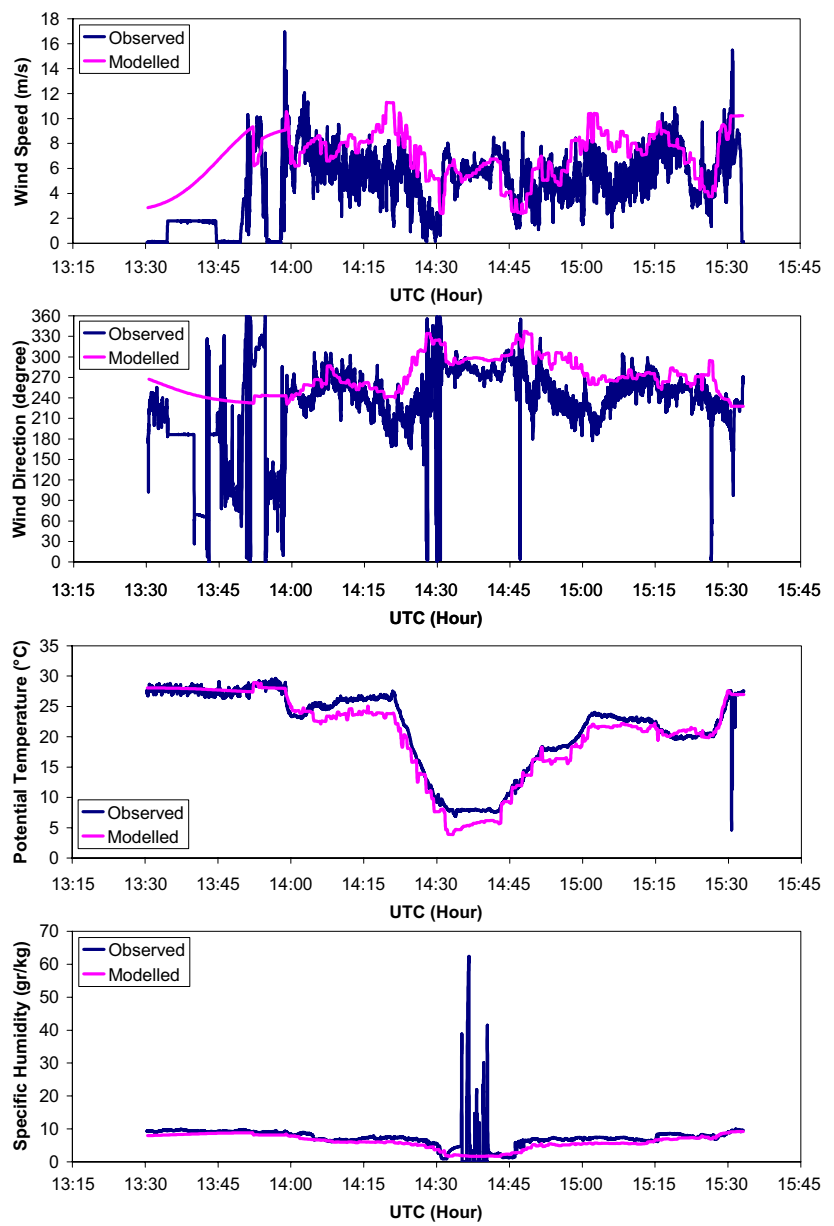

Fig. 5. Wind speed and direction, potential temperature and specific humidity for the AZTEC plane (flight of 30 June 2000 at 13:59 UTC).

note also that on the next two days, winds are weaker, with maximum values around $8 \mathrm{~ms}^{-1}$ at midday.

With respect to airborne data, (Figs. 5 and 6), temperature, specific humidity, wind speed, and direction measurements are in good agreement with model values. However, we note some essentially small differences for specific humidity, wind speed and direction around 14:38 UTC and 15:07 UTC (Fig. 5). At these times, the AZTEC plane flew at low levels (Fig. 7, where the altitude is drawn versus time). For the ARAT plane, we note that the measured wind speed and direction are slightly different from model values around 10:40 UTC (Fig. 6) in the free troposphere (Fig. 7), and around 12:30 UTC (Fig. 6) in the lower levels (Fig. 7). Finally, we can say that the simulated meteorological fields are very realistic and that they do not induce a bias for the chemical fields.
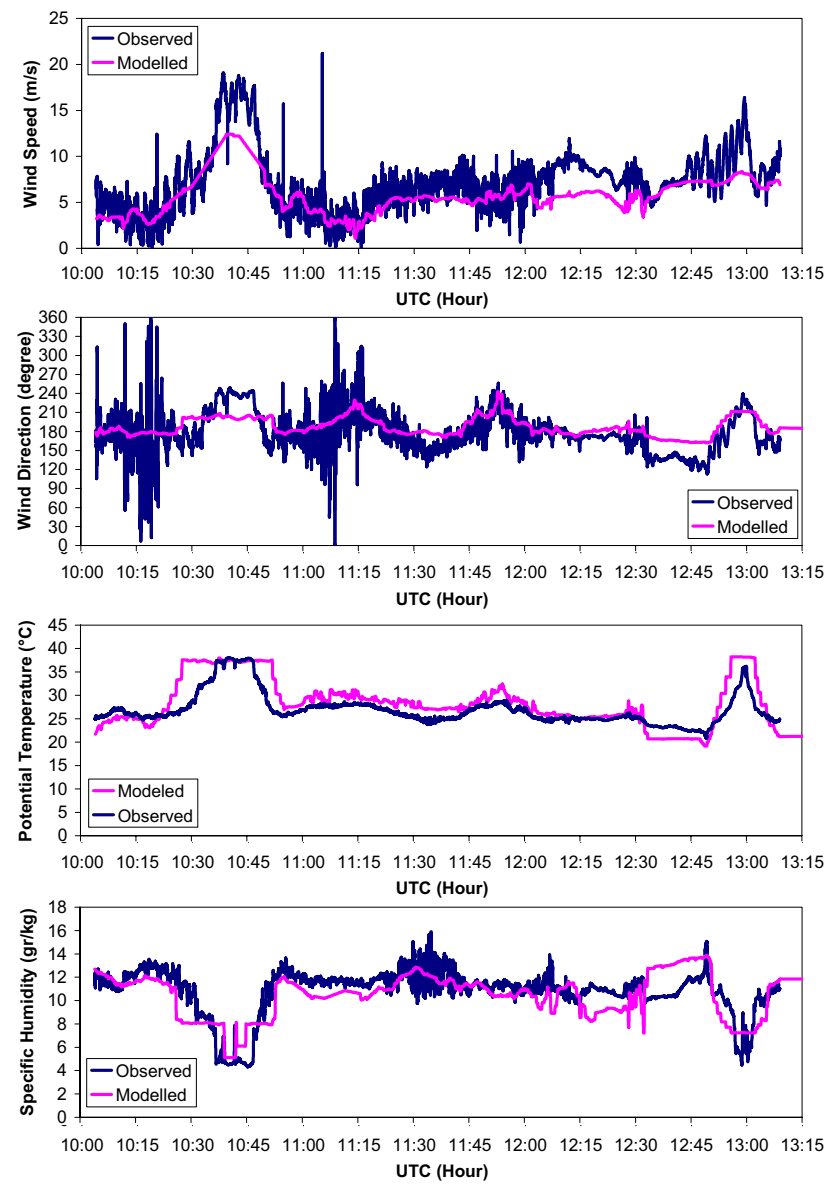

Fig. 6. Wind speed and direction, potential temperature and specific humidity for ARAT plane (flight of 1 July 2000 at 10:03 UTC).

\section{Chemical model}

The mechanism of the chemical model is given in Appendix 1. It is a condensed version of the MOCA 2.20 model (Aumont et al., 1996). It takes 29 species and 64 reactions into account. It describes the main processes driving the changes in ozone concentration in a polluted zone. The hydroperoxyl/aldehyde conversion allows a description of the degradation of the various organic compounds from anthropogenic emissions. It involves the 3 main pathways of isoprene oxidation (a species strongly emitted by Mediterranean forests). Our chemical module calculates PAN concentration, which allows a representation of the $\mathrm{NO}_{\mathrm{x}}$ transport. Finally, the chemical module includes the $\mathrm{NO}_{3} / \mathrm{N}_{2} \mathrm{O}_{5}$ equilibrium for night chemistry. It has been validated by the intercomparison protocol proposed by Kuhn et al. (1998) and Poppe et al. (1996).

The chemical solver is the QSSA or Quasi Steady State Approximation (Hesstvedt et al., 1978), faster than a matrix solver such as the Gear solver (Gear, 1971) but quite accurate (Shieh et al., 1988; Dabdud and Seinfeld, 1995; Saylor 

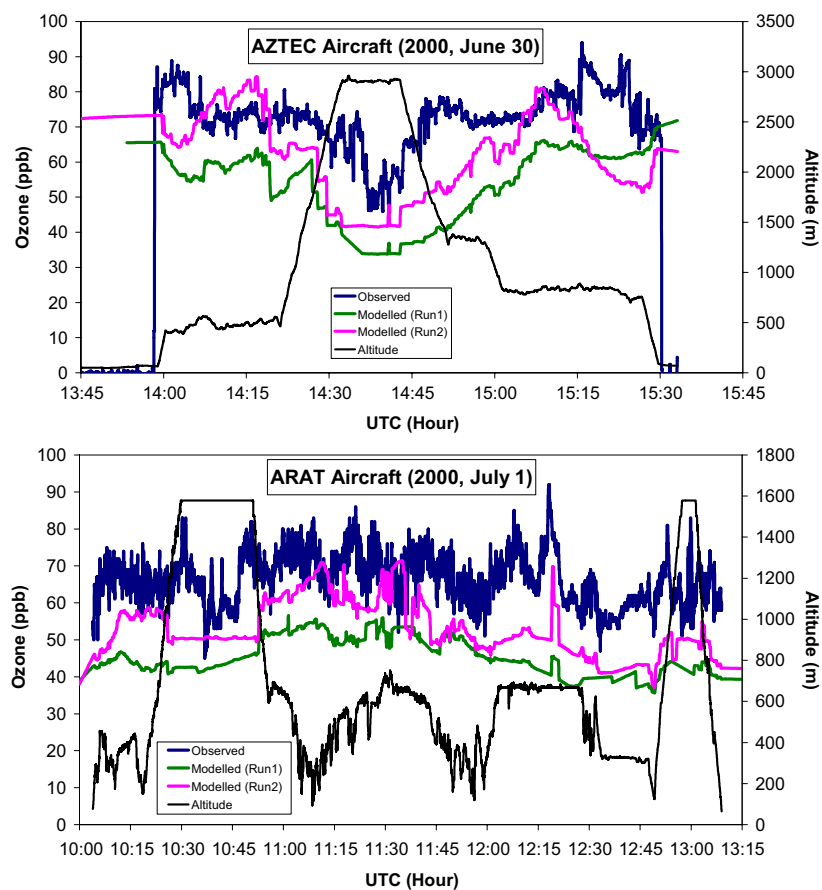

Fig. 7. Ozone concentration, observed with AZTEC plane (30 June 2000) and ARAT plane (1 July 2000), and modelled using only one grid (run 1) and using two nested grids (run 2).

and Ford, 1995). At each time step and each mesh, chemical rates are evaluated from temperature and pressure as calculated in the RAMS model. Photolysis rates are estimated from the Madronich model (Madronich, 1987), which takes the solar incident radiation and the molecular properties of the atmospheric gases into account. The photolysis rates are updated every five minutes. Actinic fluxes are estimated by Eddington approximation (Joseph et al., 1976; Wiscombe, 1997). Three photolysis reactions, not integrated in Madronich's program, have been added to this model. Quantum yield and absorption efficiency are derived from Aumont et al. (1996).

To reduce the CPU time, we have developed an original way of chemical constant rates evaluation (Poulet et al., submitted, 2004) ${ }^{2}$. Chemical kinetic coefficients are calculated from a complex expression dependent on temperature and pressure. Since temperature and pressure vary on each mesh, calculations are made for each of them and thus require a very long time. In our code, a lookup table has been created for each chemical kinetic coefficient before simulation for all the typical temperature and pressure conditions in the atmosphere. So, during the run, RAMS-chemistry merely chooses the coefficient fitted to the current meteorological conditions in the lookup table. The interest of such a method with par-

\footnotetext{
${ }^{2}$ Poulet, D., Cautenet, S., and Aumont, B.: Simulation of the chemical impact of the bush fires emissions, in central africa, during the EXPRESSO campaign, submitted to J. Geophys. Res., 2004.
}
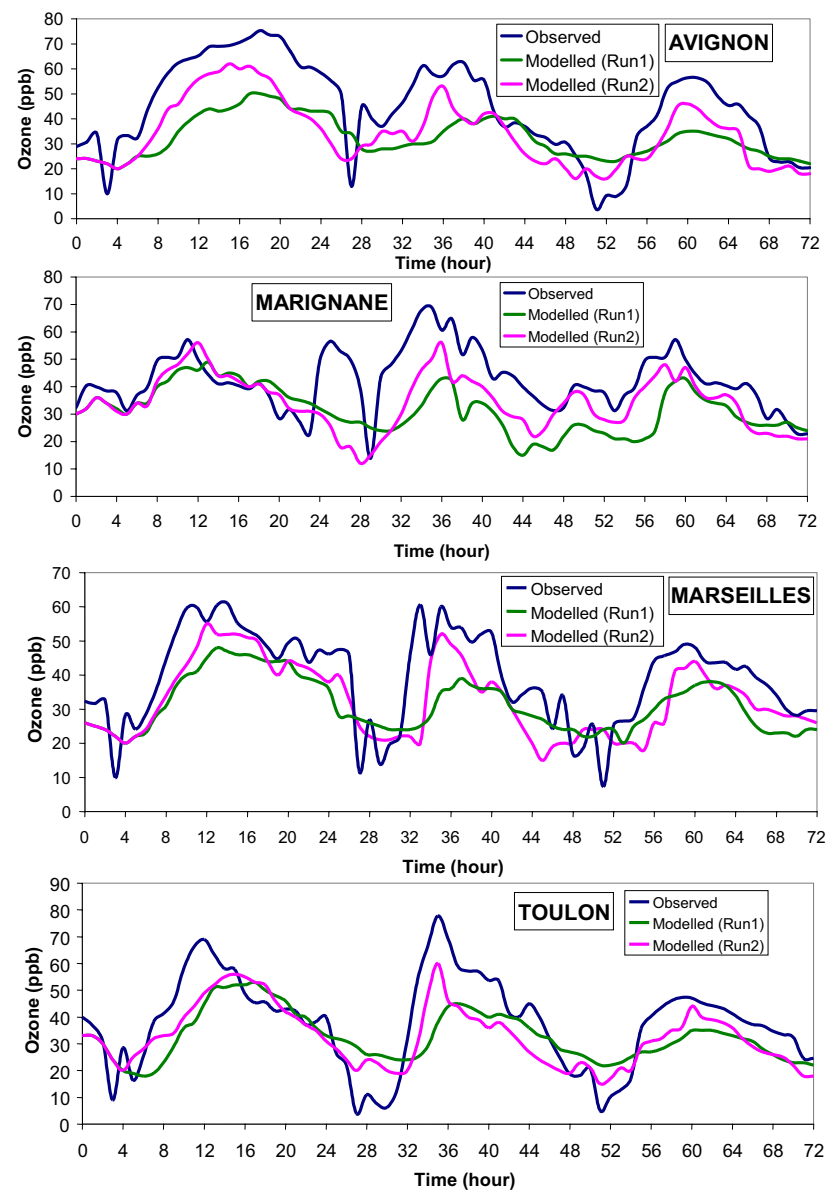

Fig. 8. Time variation (UTC) of observed and modelled (run 1 and run 2) ozone concentration (ppb) from 29 June-1 July 2000 for 4 cities: Avignon inland in north of ESCOMPTE domain, Marignane in center, Marseilles and Toulon on the coast.

allel code is that CPU time is short: it allows a significant reduction in the simulation time (for SGI 3800 computer: $1 \mathrm{~h} 30 \mathrm{CPU}$ for a simulated day).

\section{Chemical results}

In the ESCOMPTE region, the emissions are mainly of anthropogenic origin along coast (Fig. 2), and especially around the Berre Pond, but there are also biogenic emissions from the forest inland (Fig. 3). In the troposphere, ozone production is dependent on many different parameters, such as dynamical condition, radiation intensity, $\mathrm{NO}_{\mathrm{x}} / \mathrm{VOC}$ ratio, etc. It is sensitive to VOC and $\mathrm{NO}_{\mathrm{x}}$ emissions (Weimin et al., 1997). The maximum in ozone occurs when there is a high concentration in $\mathrm{VOC}$ and $\mathrm{NO}_{\mathrm{x}}$ due to emission or transport (Dodge, 1997b; Finlayson-Pitts and Pitts Jr., 1993). The sensitivity of ozone production to each of these parameters is variable. If one of these parameters is not correctly accounted for, an error in ozone estimation occurs. 

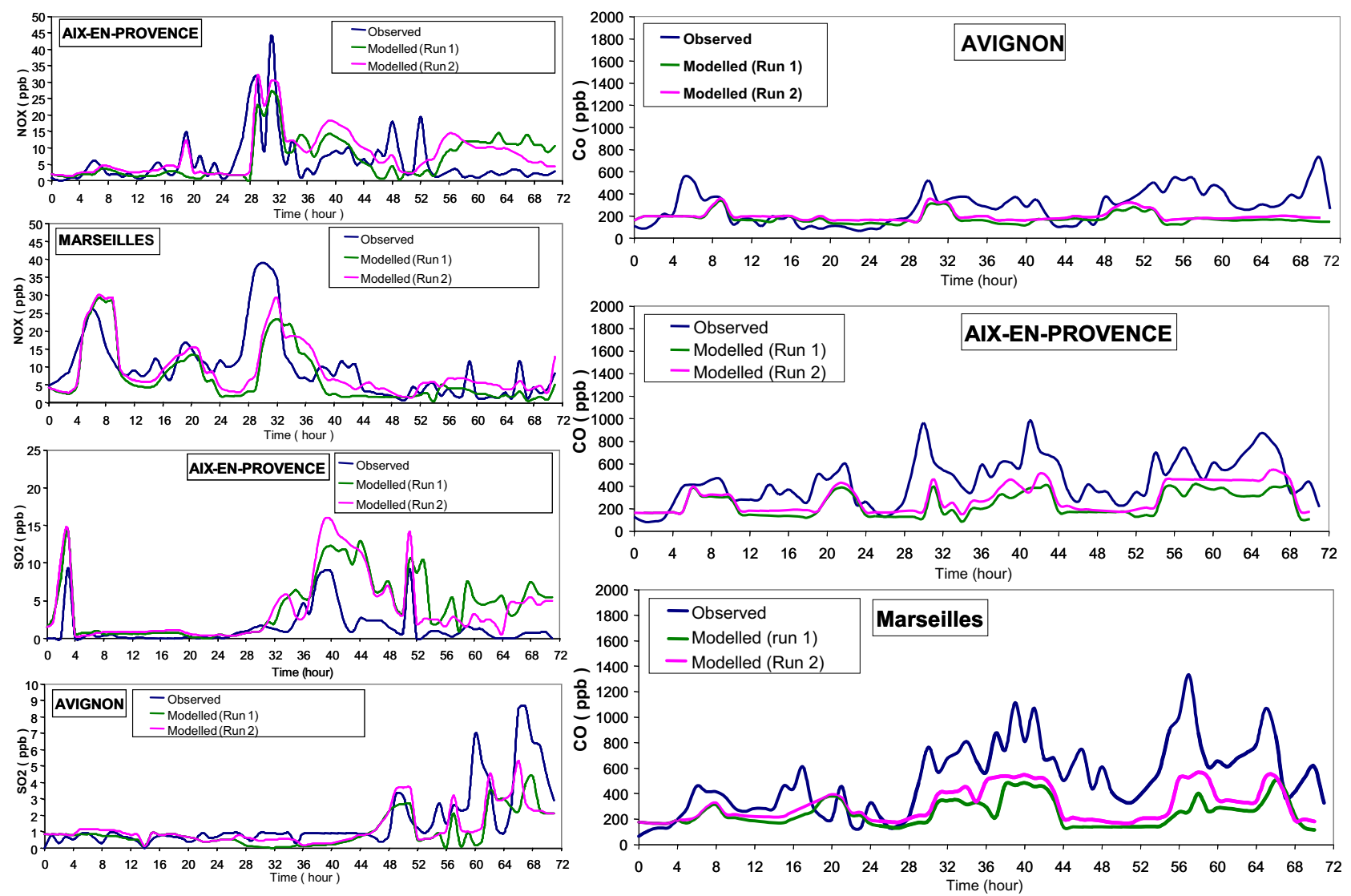

Fig. 9. Time variation (UTC) of observed and modelled (run 1 and run 2) $\mathrm{NO}_{\mathrm{x}}, \mathrm{SO}_{2}$ and $\mathrm{CO}$ concentration (ppb) from $29 \mathrm{June}-1 \mathrm{July} 2000$ for 3 cities: Avignon inland in north of ESCOMPTE domain, Aix-en-Provence close to center and Marseilles in shore.

The quality of the chemical fields depends in particular on the meteorological fields themselves. As they are quite realistic (see Sect. 6), we can study the impact of dynamics on the redistribution of chemical species. We will examine the role of nested grids to retrieve these mechanisms. However, we must keep in mind that, in this work, the emission inventory originates from a 1994 database, which may not be completely adequate.

Two runs are performed: run 1 with one grid, grid 2, which represents the ESCOMPTE region and run 2 with two nested grids (grid 1 including grid 2). To evaluate the ability of the RAMS-chemistry model, we compare the aircraft and surface station measurements with our numerical results. During the run, at each time step, the coordinates of aircraft (altitude, latitude, longitude) are noted and the fitted numerical values are written in a file. Thus the modeled values correspond exactly to the same place and the same time as the aircraft measurements.

\subsection{Aircraft measurements}

Figure 7 presents the comparisons between model results and airborne data during IOP0 for run 1 and run 2. For both flights (AZTEC and ARAT planes), the modeled ozone curve follows the observed ozone curve (same maximum and minimum), with, however, a weak but systematic underestimation in the modeled values. We think this difference could originate for two reasons: (i) our chemical model includes the main species but not all, and (ii) errors can exist in emissions rates data and in source locations. Recall that the emissions were calculated from a 1994 database for anthropogenic emissions and from a 1997 file for biogenic emissions. When the aircraft altitude is high, i.e. when the measurements are performed within the free troposphere, we note weak ozone values. For the lower levels, near the surface, the values are generally high, except for the landing or take off periods. Planes took off and landed at Marignane airport, which is very close to high emissions sources of $\mathrm{NO}_{\mathrm{x}}$ and they flew at low altitudes over smokestacks. Therefore, as there is a high $\mathrm{NO}_{\mathrm{x}}$ concentration, the ozone titration is very probable, especially in the absence of a sufficient amount of VOC. In other words, the $\mathrm{NO}_{\mathrm{x}} / \mathrm{VOC}$ ratio is not favorable for ozone formation (Finlayson-Pitts and Pitts Jr., 2000). However, we remark that for both flights run 2 gives better results than run 1 , because it takes the pollution from grid 1 into account. 


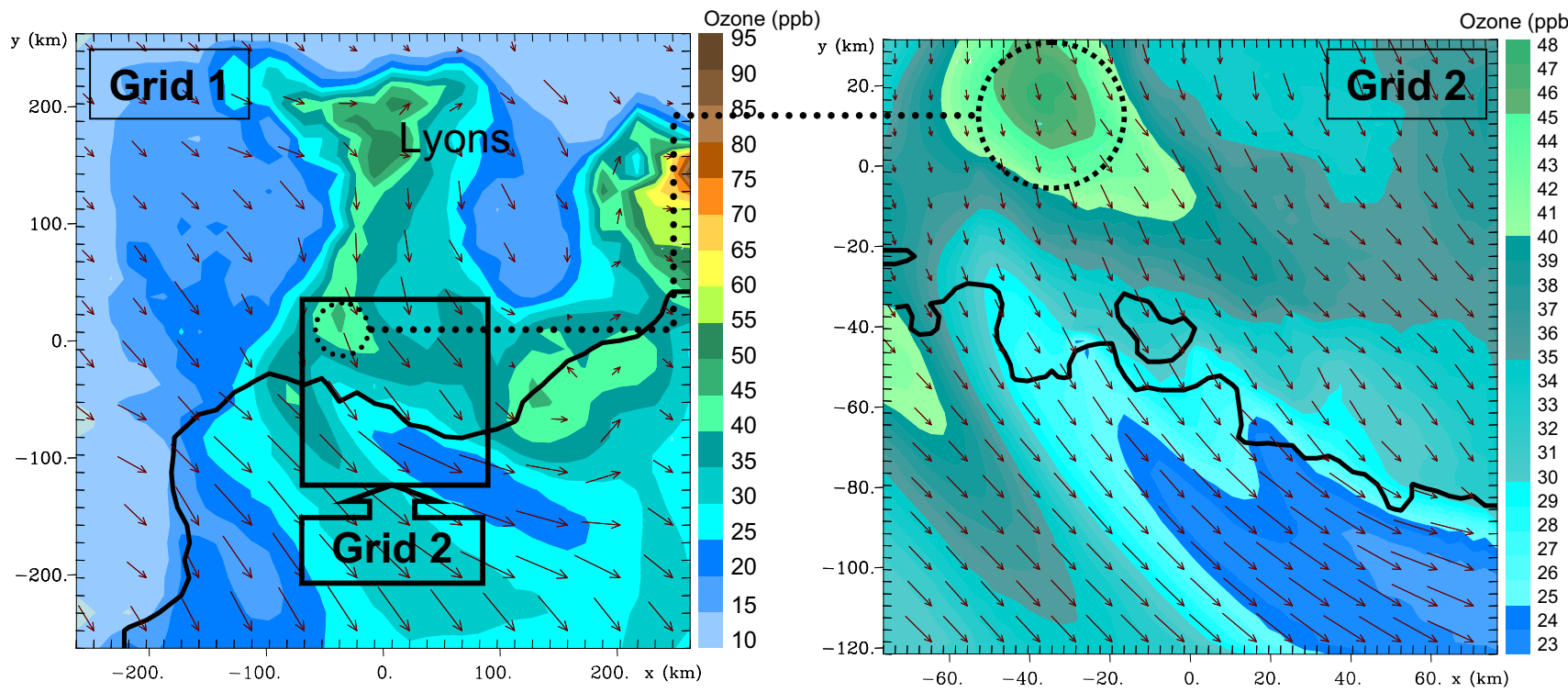

Fig. 10. Ozone concentration (ppb) and Wind speed $\left(\mathrm{ms}^{-1}\right)$ - Left: grid 1; right: grid 2; 29 June 2000 at 09:00 UTC.

\subsection{Surface stations}

For a sample of 4 selected surface stations, the numerical results are compared with the ozone, carbon monoxide, nitrogen oxides, and sulphur dioxide observations. Figure 8 shows that for these stations, the ozone results of run 2 fit the observations better than run 1. In Avignon, a town located to the north of grid 2 (Fig. 1), on 29 and 30 June (01:00 UTC to 48:00 UTC), the ozone values are higher than on 1 July (48:00 UTC to 72:00 UTC). On 29 June, the values are greater than $70 \mathrm{ppb}$ because of transport of pollutants from northern areas. On the contrary, in Marignane, Toulon and Marseilles, towns located near the coast (Fig. 1), the ozone maxima are found for 30 June. During this day, the wind is weak and the sea breeze is well developed. We have a maximum of $80 \mathrm{ppb}$ at Toulon and $70 \mathrm{ppb}$ at Marignane. Figure 9, for two stations (Marseilles and Aix), the $\mathrm{NO}_{\mathrm{x}}$ measurements are slightly different from numerical results for both runs. Again, we note that run 2 is always better than run 1. The observations show that the $\mathrm{NO}_{\mathrm{x}}$ are limited only for Aix on 29 June. The same occurs at Aix and Marseilles on 1 July (which is Saturday). The $\mathrm{NO}_{\mathrm{x}}$ levels are very strong for both towns on 30 June which is Friday (a day of departure for summer holidays). Figure 9, we can see the $\mathrm{CO}$ variations for the three days. The levels are high, particularly on 30 June and 1 July. The numerical results are better for the first day (where the traffic is regular) than the following days. In Fig. 9, we display the time evolution of the $\mathrm{SO}_{2}$ concentration for two stations (Aix and Avignon). In Aix, there is local $\mathrm{SO}_{2}$ emission. On the first day (29 June), we have a Mistral wind (northwesterly), and in this case, the morning $\mathrm{SO}_{2}$ peak is quickly dispersed. On the following days, we have a sea-breeze circulation (30 June) associated with

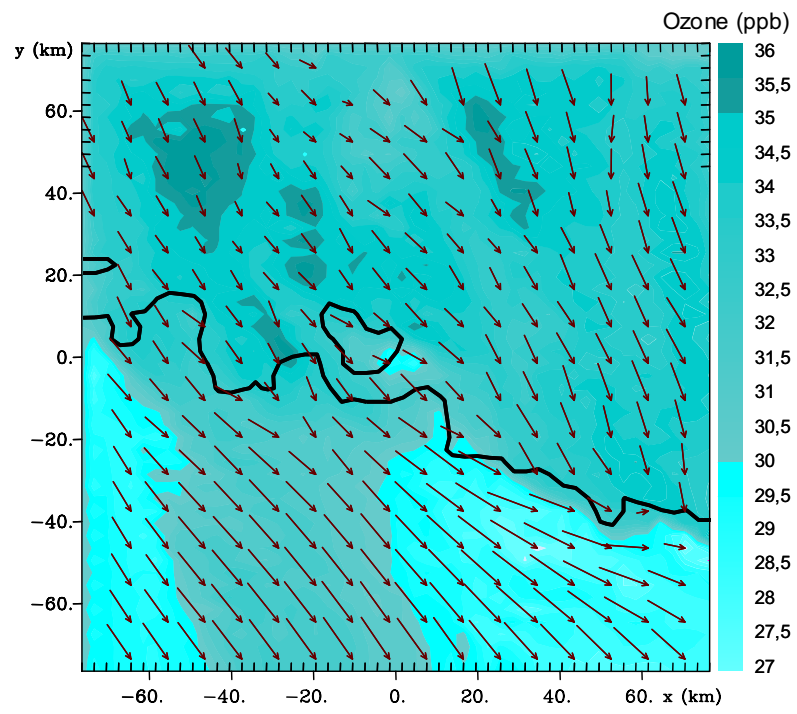

Fig. 11. Horizontal cross section for ozone concentration (ppb), 29 June 2000 at 09:00 UTC, grid 2 - simulation with one grid (run 1).

synoptic Southerly flow (1 July), and the $\mathrm{SO}_{2}$ concentration is influenced strongly by the surrounding region (Fos-Berre industrial region) which is close to Aix en Provence. In Avignon, city located the furthest inland, the levels are low, except on the last day because of synoptic transport (Southerly flow). For both cases, run 2 is slightly better than run 1 .

\subsection{Impact of dynamics}

For the four stations of Marignane, Marseilles, Toulon and Avignon, and during the three days of IOP0, we have an 


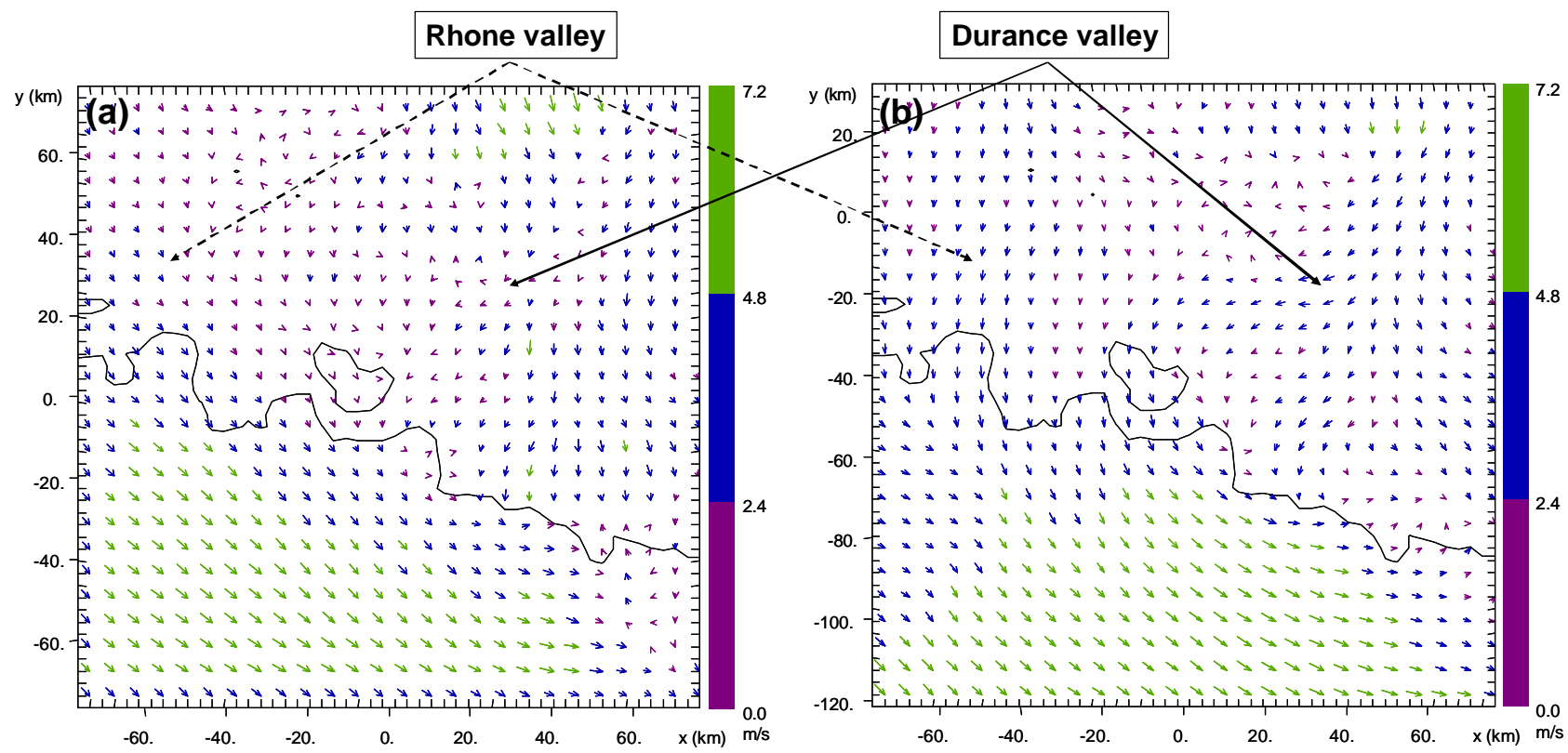

Fig. 12. Horizontal cross section at surface for wind speed $\left(\mathrm{ms}^{-1}\right), 30$ June 2000 at 07:00 UTC, grid 2 - (a) simulation with one grid (run 1); (b) simulation with two nested grids (run 2).
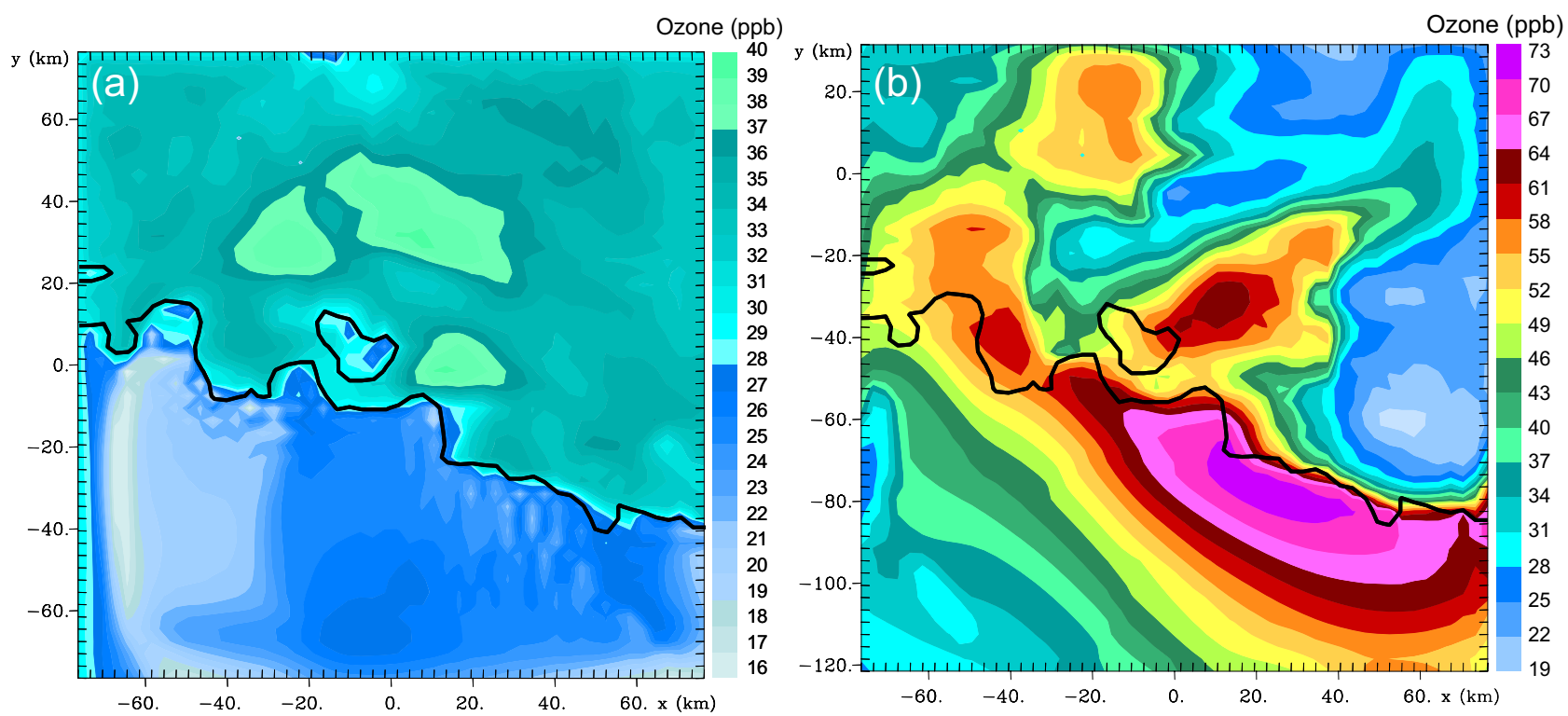

Fig. 13. Horizontal cross section at surface for ozone concentration (ppb), 30 June 2000 at 12:00 UTC, grid 2 - (a) simulation with one grid (run 1); (b) simulation with two nested grids (run 2).

ozone peak every day in spite of the fact that the meteorological and chemistry regimes are very different. The first day (Thursday, 29 June) is a normal day with regards to emissions, because the levels of $\mathrm{CO}, \mathrm{SO}_{2}$ and $\mathrm{NO}_{\mathrm{x}}$ are not very high (Fig. 9, from 00:00 UTC to 24:00 UTC). The sea breeze is weak and is associated with a northerly synoptic flow (Mistral). The ozone production is more important in Avignon than in the other cities because the channeling along the Rhone valley brings in the pollutants from the northern region. In this case, the impact of Lyons must be taken into account, and this is the reason for which run 2 is better than run 1 (Fig. 8). For this day (Fig. 10), we can see that the maximum ozone at 09:00 UTC in grid 2 is due to a northerly flow which transports the pollutants along the Rhone valley. In Fig. 11, we show the same horizontal cross section as in Fig. 10, but for run 1 (grid 2 only). The maximum in ozone 
concentration for this run is located at the same place as for run 2, but the maximum is lower ( $36 \mathrm{ppb}$ instead of $46 \mathrm{ppb}$ ). The latter value is close to the observation: at 09:00 UTC, the measured ozone concentration in Avignon, situated within the maximum area, is $50 \mathrm{ppb}$ (Fig. 8). We conclude that use of two nested grids gives more realistic results.

The second day (30 June), the traffic is very important because it is the departure of summer holidays, so that the prescribed emissions are not appropriate because they refer to a normal day. We can see in Fig. 9, from 24:00 UTC to 48:00 UTC, that the high levels in $\mathrm{NO}_{\mathrm{x}}$ and $\mathrm{CO}$ are not well retrieved, neither by run 1 nor run 2 . On the contrary, the $\mathrm{SO}_{2}$ concentration is well retrieved. We are in the case where the inventory is not adapted for $\mathrm{NO}_{\mathrm{x}}$ and CO. During this day, the northerly wind is weak and the sea breeze is well developed. The photochemistry is active and ozone peaks are higher near the coast (Marignane, Marseilles and Toulon) than inland (Avignon). If we examine the surface wind field, we can see, in Fig. 12, the channeling effect of the Rhone and Durance valleys. During the night, the catabatic wind flows down the Durance valley and this wind persists up to 07:00 UTC, on 30 June (Fig. 12b). This channeling is well retrieved, but only by run 2 . This catabatic wind brings remote air and is associated with a low value in ozone concentration, which is $27 \mathrm{ppb}$ at 12:00 UTC in the Durance valley (Fig. 13). This value is not retrieved with run 1 (around $37 \mathrm{ppb}$, Fig. 13). Once more, we conclude that the use of two nested grids improves the estimation of the surface ozone concentration.

\subsection{Impact of the emission inventory}

On the third day (1 July), we can see in Fig. 9, from 48:00 UTC to 72:00 UTC, the CO concentration is high because it is an inert gas, and, moreover, the wind is weak and therefore the diffusion is not efficient. During this day (Saturday), the traffic is less important than during the previous day. The sea breeze is associated with a weak southwesterly wind. The photochemistry is active and we have an ozone production with limited $\mathrm{NO}_{\mathrm{x}}$. We remark that the $\mathrm{SO}_{2}$ concentration is higher in Avignon than during the previous days where there is no emission, because of the southwesterly flow.

Although the 30 June and the 1 July present different chemistry and meteorological conditions, the ozone values are fairly well retrieved in both the mixed boundary layer and the free troposphere (Fig. 7).

Throughout this study, the numerical results from run 2 (two grids) better explain the redistribution of chemical species than those from run 1 (one grid). However, use of 2 nested grids is more indispensable to retrieve the ozone concentration, which is a secondary species, than the concentration of primary compounds like $\mathrm{NO}_{\mathrm{x}}$ or $\mathrm{SO}_{2}$ in a polluted region. We have remarked that the emission inventory has a strong impact for the species locally emitted. Further investigation using the measurements of the campaign in 2001 will compare the results obtained from this inventory and a new one specially built for the ESCOMPTE domain with a high resolution.

\section{Conclusions}

RAMS-Chemistry, the RAMS code coupled online with a chemistry model (MOCA 2.2), including 29 species, retrieves the maximum ozone concentrations and follows the photochemistry over a polluted zone. In an effort to save CPU time, the precalculated chemical kinetic coefficients and photolysis rates are available in look up tables. The CPU time is $1 \mathrm{~h} 30$ for a simulated day over the ESCOMPTE domain. Two runs have been performed: run 1 with one grid and run 2 with two nested grids. The simulated meteorological fields (wind, temperature, humidity) and the ozone field have been compared with aircraft measurements and at four surface stations during IOP0. Primary species like carbon oxide, nitrogen oxides and sulfur dioxide have been investigated for several stations. The 2-grid run looks substantially better than the one grid because the former takes the outer pollutants into account. This method is quite indispensable to retrieve the ozone concentration, a secondary species, whereas the concentrations of primary compounds such as $\mathrm{NO}_{\mathrm{x}}$ or $\mathrm{SO}_{2}$ are closely linked to the local emission sources, so that even a single grid run may be realistic. Of course, it is more accurate to use nested grids.

In this study, we show that the lateral boundary condition problem can be solved using nested grids for air quality models. The impact of the Rhone and Durance valley channeling has been demonstrated with run 2. Dynamic processes (synoptic flow, sea-breeze circulation, catabatic wind) are involved to explain the ozone production and the redistribution of $\mathrm{CO}, \mathrm{NO}_{\mathrm{x}}$ and $\mathrm{SO}_{2}$. These mechanisms are well simulated with two nested grids. Finally, this condensed code simulates with a good accuracy the chemical species redistribution for an urban polluted zone where the meteorological circulations are complex (topography and sea breeze).

\section{Appendix: Chemical mechanism (MOCA 2.2)}

Table 1 demonstrates the chemical mecanism used in MOCA model. 
Table 1. Chemical mechanism (MOCA 2.2).

\begin{tabular}{|c|c|c|c|c|}
\hline \multicolumn{5}{|c|}{ Chemical mechanism (MOCA 2.2) } \\
\hline $\mathrm{N}^{\circ}$ & Reaction & A & $\mathrm{N}$ & $\mathrm{E}$ \\
\hline 1 & $\mathrm{O}_{3}+\mathrm{NO} \Rightarrow \mathrm{NO}_{2}$ & $1.8 \mathrm{E}-12$ & 0 & 1370 \\
\hline 2 & $\mathrm{O}_{3}+\mathrm{NO}_{2} \Rightarrow \mathrm{NO}_{3}$ & $1.2 \mathrm{E}-13$ & 0 & 2450 \\
\hline 3 & $\mathrm{O}_{3}+\mathrm{OH} \Rightarrow \mathrm{HO}_{2}$ & $1.9 \mathrm{E}-12$ & 0 & 1000 \\
\hline 4 & $\mathrm{O}_{3}+\mathrm{HO}_{2} \Rightarrow \mathrm{OH}$ & $1.4 \mathrm{E}-14$ & 0 & 600 \\
\hline 5 & $\mathrm{NO}+\mathrm{NO}_{3} \Rightarrow \mathrm{NO}_{2}+\mathrm{NO}_{2}$ & $1.8 \mathrm{E}-11$ & 0 & -110 \\
\hline 6 & $\mathrm{NO}+\mathrm{HO}_{2} \Rightarrow$ nothing & $3.7 \mathrm{E}-12$ & 0 & -240 \\
\hline 7 & $\mathrm{NO}_{2}+\mathrm{NO}_{3} \Rightarrow \mathrm{NO}+\mathrm{NO}_{2}$ & $7.2 \mathrm{E}-14$ & 0 & 1414 \\
\hline 8 & $\mathrm{OH}+\mathrm{HO}_{2} \Rightarrow$ nothing & $4.8 \mathrm{E}-11$ & 0 & -250 \\
\hline 9 & $\mathrm{OH}+\mathrm{H}_{2} \mathrm{O}_{2} \Rightarrow \mathrm{HO}_{2}$ & $2.9 \mathrm{E}-12$ & 0 & 160 \\
\hline 10 & $\mathrm{HO}_{2}+\mathrm{HO}_{2} \Rightarrow \mathrm{H}_{2} \mathrm{O}_{2}$ & $2.2 \mathrm{E}-13$ & 0 & -620 \\
\hline 11 & $\mathrm{HO}_{2}+\mathrm{HO}_{2}+\mathrm{M} \Rightarrow \mathrm{H}_{2} \mathrm{O}_{2}+\mathrm{M}$ & $1.9 \mathrm{E}-33$ & 0 & -980 \\
\hline 12 & $\mathrm{NO}_{3}+\mathrm{HO}_{2} \Rightarrow \mathrm{HNO}_{3}$ & $9.2 \mathrm{E}-13$ & 0 & 0 \\
\hline 13 & $\mathrm{NO}_{3}+\mathrm{HO}_{2} \Rightarrow \mathrm{OH}+\mathrm{NO}_{2}$ & $3.6 \mathrm{E}-12$ & 0 & 0 \\
\hline 14 & $\mathrm{NO}+\mathrm{NO}+\mathrm{M} \Rightarrow \mathrm{NO}_{2}+\mathrm{NO}_{2}+\mathrm{M}$ & $6.93 \mathrm{E}-40$ & 0 & -530 \\
\hline 15 & $\mathrm{OH}+\mathrm{HNO}_{4} \Rightarrow \mathrm{NO}_{2}$ & $1.5 \mathrm{E}-12$ & 0 & -360 \\
\hline 16 & $\mathrm{OH}+\mathrm{CO} \Rightarrow \mathrm{HO}_{2}$ & $1.5 \mathrm{E}-13$ & 0 & 0 \\
\hline 17 & $\mathrm{OH}+\mathrm{CO}+\mathrm{M} \Rightarrow \mathrm{HO}_{2}+\mathrm{M}$ & $3.66 \mathrm{E}-33$ & 0 & 0 \\
\hline 18 & $\mathrm{NO}+\mathrm{OH}(+\mathrm{M}) \Rightarrow \mathrm{HONO}(+\mathrm{M})$ & Falloff & & \\
\hline 19 & $\mathrm{NO}_{2}+\mathrm{OH}(+\mathrm{M}) \Rightarrow \mathrm{HNO}_{3}(+\mathrm{M})$ & Falloff & & \\
\hline 20 & $\mathrm{NO}_{2}+\mathrm{HO}_{2}(+\mathrm{M}) \Rightarrow \mathrm{HNO}_{4}(+\mathrm{M})$ & Falloff & & \\
\hline 21 & $\mathrm{HNO}_{4}(+\mathrm{M}) \Rightarrow \mathrm{NO}_{2}+\mathrm{HO}_{2}(+\mathrm{M})$ & Falloff & & \\
\hline 22 & $\mathrm{NO}_{2}+\mathrm{NO}_{3}(+\mathrm{M}) \Rightarrow \mathrm{N}_{2} \mathrm{O}_{5}(+\mathrm{M})$ & Falloff & & \\
\hline 23 & $\mathrm{~N}_{2} \mathrm{O}_{5}(+\mathrm{M}) \Rightarrow \mathrm{NO}_{2}+\mathrm{NO}_{3}(+\mathrm{M})$ & Falloff & & \\
\hline 24 & $\mathrm{OH}+\mathrm{SO}_{2}(+\mathrm{M}) \Rightarrow \mathrm{HO}_{2}+\mathrm{H}_{2} \mathrm{SO}_{4}(+\mathrm{M})$ & Falloff & & \\
\hline 25 & $\mathrm{HO}_{2}+\mathrm{HO}_{2} \Rightarrow \mathrm{H}_{2} \mathrm{O}_{2}$ & Special & & \\
\hline 26 & $\mathrm{~N}_{2} \mathrm{O}_{5} \Rightarrow 2 \mathrm{HNO}_{3}$ & Special & & \\
\hline 27 & $\mathrm{O}_{3}+\mathrm{h} v \Rightarrow 2 \mathrm{OH}$ & Photolyse & & \\
\hline 28 & $\mathrm{O}_{3} \mathrm{OLSB} \Rightarrow$ nothing & Special & & \\
\hline 29 & $\mathrm{NO}_{2}+\mathrm{h} v \Rightarrow \mathrm{NO}+\mathrm{O}_{3}$ & Photolyse & & \\
\hline 30 & $\mathrm{H}_{2} \mathrm{O}_{2}+\mathrm{h} v \Rightarrow \mathrm{OH}+\mathrm{OH}$ & Photolyse & & \\
\hline 31 & $\mathrm{NO}_{3}+\mathrm{h} v \Rightarrow \mathrm{NO}$ & Photolyse & & \\
\hline 32 & $\mathrm{NO}_{3}+\mathrm{h} v \Rightarrow \mathrm{NO}_{2}+\mathrm{O}_{3}$ & Photolyse & & \\
\hline 33 & $\mathrm{HONO}+\mathrm{h} v \Rightarrow \mathrm{NO}+\mathrm{OH}$ & Photolyse & & \\
\hline 34 & $<\mathrm{RO}_{2}>+\mathrm{NO} \Rightarrow \mathrm{NO}_{2}+\mathrm{HO}_{2}$ & 4. $2 \mathrm{E}-12$ & 0 & -180 \\
\hline 35 & $<\mathrm{RO}_{2}>+\mathrm{HO}_{2} \Rightarrow \mathrm{ROOH}$ & 4. $1 \mathrm{E}-13$ & 0 & -790 \\
\hline 36 & $<\mathrm{NONO}_{2}>+\mathrm{NO} \Rightarrow \mathrm{NO}_{2}$ & 4. $2 \mathrm{E}-12$ & 0 & -180 \\
\hline 37 & $<\mathrm{NONO}_{2}>+\mathrm{HO}_{2} \Rightarrow \mathrm{ROOH}$ & 4. $1 \mathrm{E}-13$ & 0 & -790 \\
\hline 38 & $\mathrm{OH}+\mathrm{HCHO} \Rightarrow \mathrm{HO}_{2}+\mathrm{CO}$ & $1.25 \mathrm{E}-17$ & 2 & -648 \\
\hline 39 & $\mathrm{OH}+\mathrm{CH}_{3} \mathrm{CHO} \Rightarrow \mathrm{CH} 3 \mathrm{COO}_{2}$ & $5.55 \mathrm{E}-12$ & 0 & -311 \\
\hline 40 & $\mathrm{CH}_{3} \mathrm{COO}_{2}+\mathrm{NO} \Rightarrow \mathrm{NO}_{2}+\mathrm{HCHO}+<\mathrm{RO}_{2}>$ & $2.0 \mathrm{E}-11$ & 0 & 0 \\
\hline 41 & $\mathrm{HO}_{2}+\mathrm{CH} 3 \mathrm{COO}_{2} \Rightarrow 0.3 \mathrm{O}_{3}+0.7 \mathrm{ROOOH}$ & $4.3 \mathrm{E}-13$ & 0 & -1040 \\
\hline 42 & $\mathrm{C}_{2} \mathrm{H}_{5} \mathrm{CHO}+\mathrm{OH} \Rightarrow \mathrm{C}_{2} \mathrm{H}_{5} \mathrm{COO}_{2}$ & $8.5 \mathrm{E}-12$ & 0 & -252 \\
\hline 43 & $\mathrm{C}_{2} \mathrm{H}_{5} \mathrm{COO}_{2}+\mathrm{NO} \Rightarrow \mathrm{NO}_{2}+\mathrm{CH}_{3} \mathrm{CHO}+<\mathrm{RO}_{2}>$ & $2.0 \mathrm{E}-11$ & 0 & 0 \\
\hline
\end{tabular}


Table 1. Continued.

\begin{tabular}{|c|c|c|c|c|}
\hline \multicolumn{5}{|c|}{ Chemical mechanism (MOCA 2.2) } \\
\hline $\mathrm{N}^{\circ}$ & Reaction & A & $\mathrm{N}$ & $\mathrm{E}$ \\
\hline 44 & $\mathrm{C}_{2} \mathrm{H}_{5} \mathrm{COO}_{2}+\mathrm{HO}_{2} \Rightarrow 0.3 \mathrm{O}_{3}+0.7 \mathrm{ROOOH}$ & 4.3E-13 & 0 & -1040 \\
\hline 45 & $\mathrm{C}_{2} \mathrm{H}_{5} \mathrm{COO}_{2}+\mathrm{NO}_{2} \Rightarrow \mathrm{PPN}$ & $8.4 \mathrm{E}-12$ & 0 & 0 \\
\hline 46 & $\mathrm{PPN} \Rightarrow \mathrm{C}_{2} \mathrm{H}_{5} \mathrm{COO}_{2}+\mathrm{NO}_{2}$ & $1.6 \mathrm{E} 17$ & 0 & 14073 \\
\hline 47 & $\mathrm{O}_{3} \mathrm{OLSB}+\mathrm{SO}_{2} \Rightarrow \mathrm{H}_{2} \mathrm{SO}_{4}$ & $1.0 \mathrm{E}-13$ & 0 & 0 \\
\hline 48 & $\mathrm{ROOH}+\mathrm{OH} \Rightarrow \mathrm{OH}$ & $1.0 \mathrm{E}-12$ & 0 & -190 \\
\hline 49 & $\mathrm{ROOH}+\mathrm{OH} \Rightarrow<\mathrm{RO}_{2}>$ & $1.9 \mathrm{E}-12$ & 0 & -190 \\
\hline 50 & $\mathrm{ROOH}+\mathrm{OH} \Rightarrow<\mathrm{RO}_{2}>$ & Falloff & & \\
\hline 51 & $\mathrm{CH}_{3} \mathrm{COO}_{2}+\mathrm{NO}_{2}(+\mathrm{M}) \Rightarrow \mathrm{PAN}(+\mathrm{M})$ & Falloff & & \\
\hline 52 & $\mathrm{PAN}(+\mathrm{M}) \Rightarrow \mathrm{CH}_{3} \mathrm{COO}_{2}+\mathrm{NO}_{2}(+\mathrm{M})$ & Photolyse & & \\
\hline 53 & $\mathrm{HCHO}+\mathrm{h} \nu \Rightarrow 2 \mathrm{HO}_{2}+\mathrm{CO}$ & Photolyse & & \\
\hline 54 & $\mathrm{HCHO}+\mathrm{h} v \Rightarrow \mathrm{CO}$ & Photolyse & & \\
\hline 55 & $\mathrm{CH}_{3} \mathrm{CHO}+\mathrm{h} \nu \Rightarrow \mathrm{HCHO}+<\mathrm{RO}_{2}>+\mathrm{HO}_{2}+\mathrm{CO}$ & Photolyse & & \\
\hline 56 & $\mathrm{C}_{2} \mathrm{H}_{5} \mathrm{CHO}+\mathrm{h} \nu \Rightarrow \mathrm{CH}_{3} \mathrm{CHO}+<\mathrm{RO}_{2}>+\mathrm{HO}_{2}+\mathrm{CO}$ & Photolyse & & \\
\hline 57 & $\mathrm{C}_{3} \mathrm{H}_{6}+\mathrm{OH} \Rightarrow \mathrm{CH}_{3} \mathrm{CHO}+\mathrm{HCHO}+<\mathrm{RO}_{2}>$ & $4.85 \mathrm{E}-12$ & 0 & -504 \\
\hline 58 & $\mathrm{C}_{3} \mathrm{H}_{6}+\mathrm{OH} \Rightarrow \mathrm{CH}_{3} \mathrm{CHO}+\mathrm{HCHO}+<\mathrm{RO}_{2}>$ & $2.54 \mathrm{E}-11$ & 0 & -410 \\
\hline 59 & $\begin{array}{l}\text { ISOP }+\mathrm{O}_{3} \Rightarrow 0.5 \mathrm{HCHO}+0.5 \mathrm{C}_{2} \mathrm{H}_{5} \mathrm{CHO}+0.275 \mathrm{O}_{3} \mathrm{OLSB}+0.4 \mathrm{CO}+0.28 \mathrm{HO}_{2}+ \\
0.34 \mathrm{CH}_{3} \mathrm{CHO}+0.07 \mathrm{C}_{2} \mathrm{H}_{6}+0.15 \mathrm{OH}+0.31<\mathrm{RO}_{2}>\end{array}$ & $1.23 \mathrm{E}-14$ & 0 & 2013 \\
\hline 60 & $\mathrm{ISOP}+\mathrm{NO}_{3} \Rightarrow \mathrm{HCHO}+\mathrm{C}_{2} \mathrm{H}_{5} \mathrm{CHO}+\mathrm{NO}_{2}+<\mathrm{NONO}_{2}>$ & $2.54 \mathrm{E}-11$ & 0 & 1080 \\
\hline 61 & $\begin{array}{l}\mathrm{O}_{3}+\mathrm{C}_{3} \mathrm{H}_{6} \Rightarrow>0.53 \mathrm{HCHO}+0.5 \mathrm{CH}_{3} \mathrm{CHO}+0.225 \mathrm{O}_{3} \mathrm{OLSB}+0.28 \mathrm{HO}_{2}+0.4 \mathrm{CO}+ \\
0.31 \mathrm{HCHO}+0.31<\mathrm{RO}_{2}>+0.07 \mathrm{CH}_{4}+0.15 \mathrm{OH}\end{array}$ & $5.51 \mathrm{E}-15$ & 0 & 1878 \\
\hline 62 & $\mathrm{C}_{2} \mathrm{H}_{6}+\mathrm{OH} \Rightarrow>\mathrm{CH}_{3} \mathrm{CHO}+<\mathrm{RO}_{2}>$ & 4.85E-12 & 0 & -504 \\
\hline 63 & $\mathrm{C}_{2} \mathrm{H}_{4}+\mathrm{O} 3 \Rightarrow>\mathrm{HCHO}+0.37 \mathrm{O}_{3} \mathrm{OLSB}+0.44 \mathrm{CO}+0.12 \mathrm{HO}_{2}$ & $9.14 \mathrm{E}-15$ & 0 & 2580 \\
\hline 64 & $\mathrm{C}_{2} \mathrm{H}_{4}+\mathrm{OH} \Rightarrow \mathrm{a} 1 * \mathrm{HCHO}+\mathrm{a} 2 * \mathrm{CH}_{3} \mathrm{CHO}+<\mathrm{RO}_{2}>$ & $1.96 \mathrm{E}-12$ & 0 & -438 \\
\hline
\end{tabular}

* where the stoechiometric coefficients a1 and a2 depend on temperature

Acknowledgements. This modeling study is supported by funding from the French Centre National de la Recherche Scientifique (Programme National de Chimie Atmosphérique). This work makes large use of the RAMS model, which was developed under the support of the National Science Foundation (NSF) and the Army Research Office (ARO). Computer resources were provided by CINES (Centre Informatique National de l'Enseignement Supérieur), project amp2107. The authors also wish to thank the computer team of the laboratoire de Météorologie Physique de l'Université Blaise Pascal (France): A. M. Lanquette, F. Besserve and $\mathrm{Ph}$. Cacault.

Edited by: M. Kankidou

\section{References}

Aumont, B., Jaecker-Voirol, A., Martin, B., and Toupance, G.: Tests of some reduction hypotheses made in photochemical mechanisms, Atmos. Environ., 30, 2061-2077, 1996.

Bates, D. V.: Ozone: A critical review of recent experimental, clinical and epidemiological evidence, with notes causation, part 1, Canadian Respiratory Journal, 2, 25-31, 1995a.

Bates, D. V.: Ozone: A critical review of recent experimental, clinical and epidemiological evidence, with notes causation, part 2, Canadian Respiratory Journal, 2, 161-171, 1995b.

Cai, X.-M. and Steyn, D.: Modelling study of sea breezes in a complex coastal environment, Atmos. Environ., 34, 2873-2885, 2000.
Cautenet, S., Poulet, D., Delon, C., Delmas, R., Grégoire, J., Pereira, J., Cherchali, S., Amram, O., and Flouzat, G.: Simulation of carbon monoxide redistribution over central africa during biomass burning (experiment for regional sources and sinks of oxidants (EXPRESSO)), J. Geophys. Res., 104, 30 641-30 657, 1999.

Chen, S. and Cotton, W. R.: The sensitivity of a simulated extratropical mesoscale convective system to longwave radiation and ice-phase microphysics, J. Atmos. Sci., 45, 3897-3910, 1988.

Clark, T. L. and Farley, R. D.: Severe downslope windstorm calculations in two and three spatial dimensions using anelastic interactive grid nesting: A possible mechanism for gustiness, J. Atmos. Sci., 41, 329-350, 1984.

Cotton Sr., W. R. P., Walko, R. L., Liston, G. E., Tremback, C., Jiang, H., McAnely, R., Harrington, J., Nicholls, M., Carrio, G., and McFadden, J.: Rams 2001: Current status and future directions, Meteorology and Atmospheric Physics, 82, 5-29, 2003.

Cros, B., Durand, P., Cachier, H., Drobinski, P., Frejafon, E., Kottmeier, C., Perros, P. E., Ponche, J. L., Robin, D., Saïd, F., Toupance, G., and Wortham, H.: The ESCOMPTE program: An overview, Atmospheric Research, 69, 241-279, 2004.

Dabdud, D. and Seinfeld, J. H.: Extrapolation techniques used in the solution of stiff odes associated with chemical kinetics of air quality models, Atmos. Environ., 29, 403-410, 1995.

Djouad, R. and Sportisse, B.: Solving reduced chemical models in air pollution modeling, Applied Numerical Mathematics, 44, 49-61, 2003. 
Dodge, M. C.: Combined use of modelling techniques and smog chamber data to derive ozone-precursor relationships, in: Proceedings of the International Conference on Photochemical Oxidant Pollution and its Control, EPA-60/3-77-001b, edited by Dimitriades, B., 2, 881-889, 1997b.

Edy, J. and Cautenet, S.: Biomass burning: Local and regional redistribution, Air Pollution Modeling and its application, 63-69, 1998.

Finlayson-Pitts, B. J. and Pitts Jr., J. N.: Volatile organic compounds: Ozone formulation, alternative fuels, and toxics, Chemistry and Industry, 18 October, 796-800, 1993.

Finlayson-Pitts, B. J. and Pitts Jr., J. N.: Chemistry of the Upper and Lower Atmosphere, Academic Press, 2000.

François, S., Fayet, S., Grondin, E., and Ponche, J. L.: The air quality oriented atmospheric emission inventories of the ESCOMPTE program: Methodology and results, accepted in Atmospheric Research, ESCOMPTE Issue, 2004.

Gangoiti, G., Alonsoa, L., Navazoa, M., Albizurib, A., PerezLandac, G., Matabuenaa, M., Valdenebroa, V., Maruria, M., Garcia, J., and Millan, M. M.: Regional transport of pollutants over the bayof biscay: Analysis of an ozone episode under a blocking anticyclone in west-central Europe, Atmos. Environ., 36, 1349136, 2002.

Gear, C.: Numerical Initial Value Problems in Ordinary Differential Equations, Prentice-Hall, Englewood Cliffs, New Jersey, 1971.

Heck, W. W., Cure, W. W., Rawlings, J. O., Zaragoza, L. J., Heagle, A. S., Heggestead, H. E., Kohut, R. J., Kress, L. W., and Temple, P.: Assessing impacts of ozone on agricultural crops, II, crop yield functions and alternative exposure statistics, Journal of the Air Pollution Control Association, 34, 810-817, 1984.

Hesstvedt, E., Hov, O., and Isaksen, I. S.: Quasy steady state approximations in air pollution modeling: Comparison of two numerical schemes for oxidant prediction, International Journal of Chemical Kinetics, 10, 971-994, 1978.

Joseph, J. H., Wiscombe, W. J., and Weinman, J. A.: The deltaeddington approximation for radiative flux transfer, J. Atmos. Sci., 33, 2452-2459, 1976.

Kuhn, M., Builtjes, P. J. H., Poppe, D., Simpson, D., Stockwell, W. R., Andersson-Sköld, Y., Baart, A., Das, M., Fiedler, F., Hov, Ø., Kirchner, F., Makar, P. A., Milford, J. B., Roemer, M. G. M., Ruhnke, R., Strand, A., Vogel, B., and Vogel, H.: Intercomparaison of the gase-phase chemistry in several chemistry and transport models, Atmos. Environ., 32, 693-709, 1998.

Lyons, A., Tremback, C. J., and Pielke, R. A.: Applications of the regional atmospheric systems (RAMS) to provide input to photochemical grid models for the lake michigan ozone study (LMOS), Journal of Applied Meteorology, 34, 1762-1785, 1995.

Madronich, S.: Photodissociation in the atmosphere, 1. Actinic flux and the effects of ground reflections and clouds, J. Geophys. Res., 92, 9740-9752, 1987.

Madronich, S. and Calvert, J. G.: The NCAR master mechanism of the gas phase chemistry, Technical Note 2.0, NCAR, 1989.

Millan, M., Salvador, R., Mantilla, E., and Kallos, G.: Photooxidant dynamics in th mediterranean basin in summer: Results from european research projects, J. Geophys. Res., 102, 8811-8823, 1997.
Poppe, D., Andersson-Sköld, Y., Baart, A., Builtjes, P. J. H., Das, M., Fiedler, F., Hov, Ø., Kirchner, F., Kuhn, M., Makar, P. A., Milford, J. B., Roemer, M. G. M., Simpson, R. R. D., Stockwell, W. R., Strand, A., Vogel, B., and Vogel, H.: Gas-phase reactions in atmospheric chemistry and transport models: A model intercomparison, EUROTRAC special publication, ISS, 1996.

Saylor, R. D. and Ford, G. D.: On the comparison of numerical methods for the integration of kinetic equations in atmospheric chemistry and transport model, Atmos. Environ., 29, 2585-2593, 1995.

Shieh, D. S.-S., Chang, Y., and Carmichael, G. R.: The evaluation of numerical techniques for solution of stiff ordinary differential equations arising from chemical kinetic problems, Environmental Software, 3, 28-38, 1988.

Simon, V., Luchetta, L., and Torres, L.: Estimating the emission of volatile organic compounds (VOC) from the french forest ecosystem, Atmos. Environ., 35 Supplement No. 1, S115-S126, 2001.

Taghavi, M., Cautenet, S., and Arteta, J.: Impact of a high resolution emission inventory on modeling accuracy, accepted for Atmospheric Research, ESCOMPTE Issue, 2004.

Taylor, O. C.: Importance of peroxyacetyl nitrate (PAN) as a phototoxic air pollutant, Journal of the Air Pollution Control Association, 19, 347-351, 1969.

Thunis, P. and Cuvelier, C.: Impact of biogenic emissions on ozone formation in the mediterranean area - a BEMA modelling study, Atmos. Environ., 34, 467-481, 2000.

Tripoli, G. J. and Cotton, W. R.: The colorado state university threedimensional cloud/mesoscale model, Part i: General theoretical framework and sensitivity experiments, J. de Rech. Atmos., 16, 185-220, 1982.

VanLoon, M., Builtjes, P. J. H., and Segers, A. J.: Data assimilation of ozone in the atmospheric transport chemistry model LOTOS, Environmental Modelling, 15, 603-609, 2000.

Vitousek, P. M., Aber, J. D., Howarth, R. W., Likens, G. E., Matson, P. A., Schindler, D. W., Schlesinger, W. H., and Tilman, D. G.: Human alteration of the global nitrogen cycle: Sources and consequences, Ecological Application, 7, 737-750, 1997.

Walko, R. L., Tremback, C. J., Pielke, R. A., and Cotton, W. R.: An interactive nesting algorithm for stretched grids and variable nesting ratios, Journal of Applied Meteorology, 34, 994-999, 1995.

Weimin, J., Donald, L., Singleton, M. H., and McLaren, R.: Sensitivity of ozone concentrations to VOC and NOx emissions in the canadian lower fraser valley, Atmos. Environ., 31, 627-638, 1997.

Winner, D. A., Cass, C. R., and Harley, R. A.: Effect of alternative boundary condition on predicted ozone control strategy performance: A case study in los angeles area, Atmos. Environ., 29, 3451-3464, 1995.

Wiscombe, W. J.: The delta-m method: Rapid yet accurate radiative flux calculations for strongly asymetric phase functions, J. Atmos. Sci., 34, 1408-1422, 1997. 